Article

\title{
Sodium Acetate Orientated Hollow/Mesoporous Magnetite Nanoparticles: Facile Synthesis, Characterization and Formation Mechanism
}

\author{
Quanguo $\mathrm{He}^{\dagger}{ }^{\dagger}$ Jun Liu ${ }^{\dagger}$, Jing Liang, Xiaopeng Liu, Ziyu Ding, Du Tuo and Wen $\mathrm{Li}^{*}$ \\ School of Life Science and Chemistry, Hunan University of Technology, Zhuzhou 412007, China; \\ hequanguo@126.com (Q.H.); liu.jun.1015@163.com (J.L.); liangjingabbey@126.com (J.L.); \\ amituo321@163.com (X.L.); dingziyu0320@163.com (Z.D.); dutuo99@hut.edu.cn (D.T.) \\ * Correspondence: liwendream@163.com; Tel.: +86-731-22183882 \\ † These authors contributed equally to the work.
}

Received: 22 January 2018; Accepted: 9 February 2018; Published: 16 February 2018

Featured Application: Magnetite nanoparticles with controllable sizes and spatial structures are promising to be applied in magnetic fluid, high performance batteries, magnetic targeting and imaging, and drug delivery systems related biomedical field.

\begin{abstract}
Monodispersed magnetite $\left(\mathrm{Fe}_{3} \mathrm{O}_{4}\right)$ nanospheres with hollow or porous interior structures were synthesized by a facile one-pot solvothermal route. The facile synthetic process was carried out by using iron (III) chloride hexahydrate $\left(\mathrm{FeCl}_{3} \cdot 6 \mathrm{H}_{2} \mathrm{O}\right)$ as only ferric ion resource, and anhydrous sodium acetate ( $\mathrm{NaAc}$ ) as structure-directing agent in an ethylene glycol solution without any templates or surfactants involved. The sizes, morphologies, crystal structures and magnetic properties of hollow $\mathrm{Fe}_{3} \mathrm{O}_{4}$ NPs are characterized via Scanning electron microscopy (SEM), Transmission electron microscopy (TEM), X-ray powder diffraction (XRD) and Vibrating sample magnetometer (VSM) techniques. The influences of reaction time, molar ratio of reactants on the morphologies and magnetic performances are also investigated. The different morphologies of magnetite $\left(\mathrm{Fe}_{3} \mathrm{O}_{4}\right)$ particles were presented with tunable size ranging from 85 to $250 \mathrm{~nm}$ and controllable structures including porous and hollow construction by using different amount of anhydrous NaAc. A plausible mechanism based on sodium acetate assistant local Ostwald ripening is proposed for acquiring the tailorable morphology and magnetic performance. Such a design conception of anhydrous $\mathrm{NaAc}$ assisted Ostwald ripening applied here is a significant alternative for synthesizing hollow magnetic particles, and it could elucidate some light to understand and construct other novel hollow/mesoporous nanostructures.
\end{abstract}

Keywords: solvothermal synthesis; hollow/mesoporous structures; anhydrous sodium acetate $(\mathrm{NaAc})$ assistance; magnetite $\left(\mathrm{Fe}_{3} \mathrm{O}_{4}\right)$

\section{Introduction}

Since nanotechnology have been rapidly developed in recent decades, nanomaterials with high performances attract a lot of attentions in various applications. Recently, hollow nanoparticles (NPs) are synthesized successfully for practical application, such as catalysis, lithium ion battery and biomedicine because the large surface area and hollow/porous structures are facilitated to loading more drugs or increasing more active reaction sites. Especially, the hollow magnetic $\left(\mathrm{Fe}_{3} \mathrm{O}_{4}\right)$ NPs show more potentiality in multi-functional application, including fundamental size-dependent magnetism/optoelectronics and targeted drug delivery application due to their low toxicity [1-5].

Various methods, including hard template method [6-8], soft template method [9], free template method $[10,11]$ and sacrificial template method [12-15] are employed for synthesis of hollow iron 
oxide NPs. In particular, as for the hard template method, the greatest merit of it is that the grain size of the hollow structure is controllable. However, these steps are cumbersome and the hollow NPs are easy to collapse after removing the template. Comparatively, the soft template method is a low-cost technique for synthesis of hollow $\mathrm{Fe}_{3} \mathrm{O}_{4}$. However, the large particle size could restrict its practical application. Moreover, hollow $\mathrm{Fe}_{3} \mathrm{O}_{4}$ with small size could be precisely synthesized by sacrificial template method. Nanoscale Kirkendall effect is a typical mechanism for explaining the formation of hollow $\mathrm{Fe}_{3} \mathrm{O}_{4}$, which could be exploited and extended for synthesis with metal-containing starting materials. Additionally, the free template method is a common method for preparing the hollow nanostructure, it is easy to operate and to prepare the NPs with uniform size distribution [16-18]. This method could also be used for synthesis of hollow / mesoporous $\mathrm{Fe}_{3} \mathrm{O}_{4} \mathrm{NPs}$. But the disadvantage of this method is that the hollow diameter cannot be precisely controlled by artificial regulation.

Hydrothermal route is a typical free template method, and during hydrothermal process, the iron oxide nanoparticle with different morphology and particle sizes could be synthesized by changing the structure direct agents [19-22]. For example, Lin X. and co-workers [23] prepared a variety of hollow magnetic NPs by a simple hydrothermal method. Ethylene glycol was used as solvent and reducing agent, and a variety of ammonium salts were added as structure-directing agent for synthesis of the hollow $\mathrm{Fe}_{3} \mathrm{O}_{4} \mathrm{NPs}$ with various morphologies. Moreover, in our previous work [24,25], the monodisperse $\mathrm{Fe}_{3} \mathrm{O}_{4}$ hollow/mesoporous spheres were synthesized by using ammonium acetate $\left(\mathrm{NH}_{4} \mathrm{Ac}\right)$ and ammonium bicarbonate $\left(\mathrm{NH}_{4} \mathrm{HCO}_{3}\right)$ as a structural guide agent. The produced $\mathrm{NH}_{3}$ and $\mathrm{CO}_{2}$ bubbles could be responsible for hollow and mesoporous formation, respectively. After regulating the ratio of $\mathrm{NH}_{4} \mathrm{Ac}$ and $\mathrm{NH}_{4} \mathrm{HCO}_{3}$, the $\mathrm{Fe}_{3} \mathrm{O}_{4} \mathrm{NPs}$ with different morphologies were obtained correspondingly.

However, as most literatures reported, the particle-sizes of hollow $\mathrm{Fe}_{3} \mathrm{O}_{4}$ NPs are always larger than $200 \mathrm{~nm}$ via hydrothermal method, and the intensity of saturation magnetization $\left(M_{s}\right)$ is not satisfied for targeting applications. As a result, an alternative method to fabricate size-controllable magnetite NPs with hollow/mesoporous structure remains as a currently lasting challenge. Herein, hollow/mesoporous $\mathrm{Fe}_{3} \mathrm{O}_{4} \mathrm{NPs}$ with different particle-sizes are synthesized by facile hydrothermal method. Iron (III) chloride hexahydrate $\left(\mathrm{FeCl}_{3} \cdot 6 \mathrm{H}_{2} \mathrm{O}\right)$ is used as the only ferric ion resource, and anhydrous sodium acetate $(\mathrm{NaAc})$ is acted as structure-directing agent to prepare hollow or mesoporous magnetite $\left(\mathrm{Fe}_{3} \mathrm{O}_{4}\right)$ NPs in ethylene glycol solution under $200{ }^{\circ} \mathrm{C}$. The sizes, morphologies, crystal structures and magnetic properties of $\mathrm{Fe}_{3} \mathrm{O}_{4} \mathrm{NPs}$ are carefully characterized by SEM, TEM, XRD and VSM. The influences of reaction time, molar ratio of reactants on the morphologies and magnetic performances are also investigated. Finally, the formation mechanism of these $\mathrm{Fe}_{3} \mathrm{O}_{4}$ NPs is proposed.

\section{Experimental Section}

\subsection{Material and Methods}

Ferric chloride hexahydrate $\left(\mathrm{FeCl}_{3} \cdot 6 \mathrm{H}_{2} \mathrm{O}\right)$, anhydrous sodium acetate (NaAc), ethylene glycol (EG), ethanol (99.7\%) and other chemical reagents with analytical grade were purchased from Sinopharm Chemical Reagent Co., Ltd. (Shanghai, China). Millipore water $\left(18.2 \mathrm{M} \Omega \mathrm{cm}\right.$ at $\left.25^{\circ} \mathrm{C}\right)$ was used throughout all experiments. Field emission Transmission electron microscopy (TEM) images were taken using a Hitachi JEM-1230 (JEOL, Tokyo, Japan) transmission electron microscope at an accelerating voltage of $200 \mathrm{kV}$. Scanning electron microscopy (SEM) images were obtained using a Hitachi S-3000 (Hitachi, Tokyo, Japan). X-ray powder diffraction (XRD) measurements were performed on a Bruker Advanced-D8 (Bruker AXS GmbH, Karlsruhe, Germany) Nanoparticle size analyzer patterns were taken at Malvern Zetasizer Nano S90 (Malvern, Worcestershire, UK), The HH-15 vibrating sample magnetometer (VSM) (Nanjing University Instrument Factory, Nanjing Institute of Electronics Ding one hundred, Nanjing, Jiangsu, China) was used in the magnetic measurement. The 
stopwatch timer (Tianfu PC2360, Zhejiang winds sporting goods factory, Yiwu City, Zhejiang, China) was measured the reaction time.

\subsection{Synthesis of Hollow/Mesoporous Fe3O4 NPs}

A certain amount of $\mathrm{FeCl}_{3} \cdot 6 \mathrm{H}_{2} \mathrm{O}$ was dissolved in $40 \mathrm{~mL}$ of EG to form a clear solution, followed by adding a certain amount of anhydrous $\mathrm{NaAc}$ (The specific parameters were presented in Table 1.) The mixture was vigorously mixed by ultrasonication for formation of a homogeneous solution. Then, the solution was transferred into a Teflon-lined stainless steel autoclave ( $100 \mathrm{~mL}$ capacity) for hydrothermal treatment at $200{ }^{\circ} \mathrm{C}$ for $5-20 \mathrm{~h}$. After the autoclave was allowed to cool down to room temperature, the precipitate was collected by magnetic separation and washed by water and ethanol for several times under sonication. Finally, the products are dried under vacuum at room temperature.

Table 1. The major morphology of samples obtained in specific experimental condition, $\mathrm{A}: \mathrm{FeCl}_{3} \cdot 6 \mathrm{H}_{2} \mathrm{O}$, B: NaAc.

\begin{tabular}{|c|c|c|c|c|c|c|c|c|}
\hline Parameter & Sample No. & A mmol & B mmol & A:B & $\begin{array}{l}\text { Reaction } \\
\text { Time } \\
\text { (hours) }\end{array}$ & $\begin{array}{c}\text { Reaction } \\
\text { Tempereture } \\
\left({ }^{\circ} \mathrm{C}\right)\end{array}$ & $\begin{array}{c}\text { Average } \\
\text { Dimension } \\
(\mathrm{nm})\end{array}$ & Major Morphology \\
\hline \multirow{3}{*}{$\mathrm{n}(\mathrm{A})$} & S1 & 0.4 & 40 & $1: 100$ & 10 & 200 & 101 & $\begin{array}{l}\text { Little hollow structure with } \\
\text { small solid particles }\end{array}$ \\
\hline & S2 & 5 & 40 & $1: 8$ & 10 & 200 & 222 & Hollow structure \\
\hline & S3 & 10 & 40 & $1: 4$ & 10 & 200 & 116 & Mesoporous structure \\
\hline \multirow{3}{*}{$\mathrm{n}(\mathrm{B})$} & S5 & 5 & 5 & $1: 1$ & 10 & 200 & 85 & $\begin{array}{l}\text { Microcrystalline grain, bulk } \\
\text { structure }\end{array}$ \\
\hline & S6 & 5 & 10 & $1: 2$ & 10 & 200 & 122 & $\begin{array}{l}\text { Hollow structure with hole } \\
\text { in the wall }\end{array}$ \\
\hline & S7 & 5 & 20 & $1: 4$ & 10 & 200 & 103 & $\begin{array}{c}\text { Flowerlike nanospheres } \\
\text { with Mesoporous structure }\end{array}$ \\
\hline \multirow{6}{*}{$\begin{array}{l}\text { Reaction } \\
\text { Time }\end{array}$} & $\mathrm{S} 10$ & 5 & 40 & $1: 8$ & 5 & 200 & 184 & $\begin{array}{l}\text { larger particles without } \\
\text { obvious hollow structure }\end{array}$ \\
\hline & S11 & 5 & 40 & $1: 8$ & 6 & 200 & 212 & $\begin{array}{l}\text { larger particles without } \\
\text { obvious hollow structure }\end{array}$ \\
\hline & S12 & 5 & 40 & $1: 8$ & 8 & 200 & 217 & Hollow structure \\
\hline & $\mathrm{S} 13$ & 5 & 40 & $1: 8$ & 10 & 200 & 222 & Hollow structure \\
\hline & S14 & 5 & 40 & $1: 8$ & 12 & 200 & 213 & Hollow structure \\
\hline & S15 & 5 & 40 & $1: 8$ & 20 & 200 & 241 & Hollow structure \\
\hline
\end{tabular}

\section{Result and Discussion}

The influences of reaction time, molar ratio of $\mathrm{FeCl}_{3} \cdot 6 \mathrm{H}_{2} \mathrm{O}$ and anhydrous $\mathrm{NaAc}$ on the sizes, morphologies, crystal structures and magnetic properties of these hollow or mesoporous $\mathrm{Fe}_{3} \mathrm{O}_{4} \mathrm{NPs}$ are carefully investigated by SEM, TEM, XRD and VSM techniques.

\subsection{Morphology, Crystal Structure, and Magnetic Property of $\mathrm{Fe}_{3} \mathrm{O}_{4} \mathrm{NPs}$ with Different Amount of $\mathrm{FeCl}_{3} \cdot 6 \mathrm{H}_{2} \mathrm{O}$}

In this section, four experimental groups are carried out for investigating the influence of $\mathrm{FeCl}_{3} \cdot 6 \mathrm{H}_{2} \mathrm{O}$ on the morphology of $\mathrm{Fe}_{3} \mathrm{O}_{4} \mathrm{NPs}$. By only changing the initial amount of $\mathrm{FeCl}_{3} \cdot 6 \mathrm{H}_{2} \mathrm{O}$ (0.4 mmol (S1), $5 \mathrm{mmol}$ (S2), $10 \mathrm{mmol}$ (S3) and $20 \mathrm{mmol}(\mathrm{S} 4)$ ), the $\mathrm{Fe}_{3} \mathrm{O}_{4} \mathrm{NPs}$ with different performances are obtained (The specific parameters are presented in Table 1). Firstly, the SEM images of as-synthesized $\mathrm{Fe}_{3} \mathrm{O}_{4} \mathrm{NPs}$ are presented in Figure 1. As shown in the SEM images, the mean particle size of $\mathrm{Fe}_{3} \mathrm{O}_{4} \mathrm{NPs}$ (S1) are smaller than $100 \mathrm{~nm}$ when $0.4 \mathrm{mmol}$ of $\mathrm{FeCl}_{3} \cdot 6 \mathrm{H}_{2} \mathrm{O}$ was added (Figure $1 \mathrm{~A}$ ). The mean particle size of $\mathrm{Fe}_{3} \mathrm{O}_{4} \mathrm{NPs}$ (S2) is increasing to $200 \mathrm{~nm}$ when the amount of $\mathrm{FeCl}_{3} \cdot 6 \mathrm{H}_{2} \mathrm{O}$ is $5 \mathrm{mmol}$. (Figure 1B), and the dispersity is better than these NPs in Figure 1A. As shown in Figure 1C, 
nearly monodispersed $\mathrm{Fe}_{3} \mathrm{O}_{4}$ NPs (S3) with mean particle sizes between 100 and $200 \mathrm{~nm}$ are obtained when the $\mathrm{FeCl}_{3} \cdot 6 \mathrm{H}_{2} \mathrm{O}$ increase to $10 \mathrm{mmol}$. The SEM images in Figure $1 \mathrm{D}$ indicate that the average size of as prepared $\mathrm{Fe}_{3} \mathrm{O}_{4}$ NPs (S4) is less than $100 \mathrm{~nm}$.
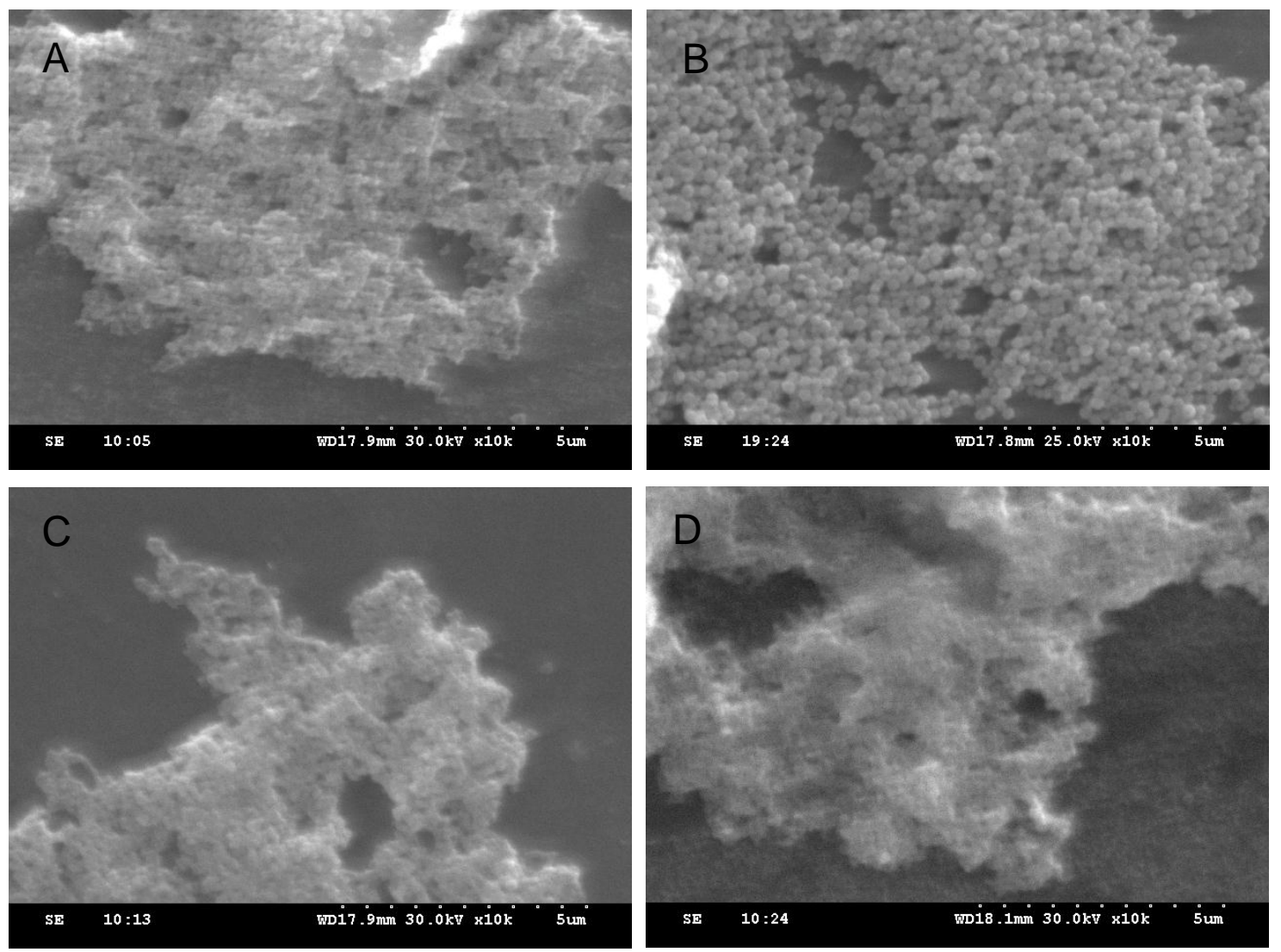

Figure 1. SEM images of $\mathrm{Fe}_{3} \mathrm{O}_{4}$ with different molar quantity of $\mathrm{FeCl}_{3} \cdot 6 \mathrm{H}_{2} \mathrm{O}$, (A) $0.4 \mathrm{mmol}$; (B) 5 mmol; (C) $10 \mathrm{mmol}$; (D) $20 \mathrm{mmol}$.

The TEM images and corresponding particle size distribution of the as-prepared $\mathrm{Fe}_{3} \mathrm{O}_{4} \mathrm{NPs}$ are presented in Figure 2. The S1 showed spherical morphology with average particle size of $101 \mathrm{~nm}$ (Figure 2A,E). But the size distribution is wide, and the hollow structure is not obvious. After increasing the amount of $\mathrm{FeCl}_{3} \cdot 6 \mathrm{H}_{2} \mathrm{O}$ to $5 \mathrm{mmol}$, the hollow structure of as-obtained $\mathrm{Fe}_{3} \mathrm{O}_{4} \mathrm{NPs}$ (S2) is more apparent, and the mean particle size is $222 \mathrm{~nm}$ (Figure 2B,F). The average particles size of S3 is $116 \mathrm{~nm}$, and the internal mesoporous structure could be observed in Figure 2C,G. Moreover, with the increasing of $\mathrm{FeCl}_{3} \cdot 6 \mathrm{H}_{2} \mathrm{O}$, the flower-like $\mathrm{Fe}_{3} \mathrm{O}_{4} \mathrm{NPs}$ without hollow and mesoporous structure are presented in Figure 2D,H. These results indicated that the morphology could be influenced by the amount of $\mathrm{FeCl}_{3} \cdot 6 \mathrm{H}_{2} \mathrm{O}$ greatly.

Moreover, the XRD patterns of these $\mathrm{Fe}_{3} \mathrm{O}_{4}(\mathrm{~S} 1-\mathrm{S} 4)$ are shown in Figure 3. The XRD is conducted to confirm the crystal structure and composition of these samples. As shown in Figure 3, the peaks at $2 \theta=25.7^{\circ}, 30.4^{\circ}, 35.7^{\circ}, 43.2^{\circ}, 57.3^{\circ}$ and $62.8^{\circ}$ are evidently observed in these curves, and these peaks could index to the crystal planes of (111), (220), (311), (400), (511) and (440) of $\mathrm{Fe}_{3} \mathrm{O}_{4}$ (JCPDS PDF: $01-1111, \alpha=8.393 \AA$ ), respectively. There are no other impurity peaks in these curves, it indicates that the as-prepared $\mathrm{Fe}_{3} \mathrm{O}_{4}$ NPs possess inverse spinel phase. Meanwhile, the intensities of S1-S4 is increasing gradually. It indicates that the $\mathrm{FeCl}_{3} \cdot 6 \mathrm{H}_{2} \mathrm{O}$ could influence the crystal performance of as-prepared $\mathrm{Fe}_{3} \mathrm{O}_{4} \mathrm{NPs}$. 


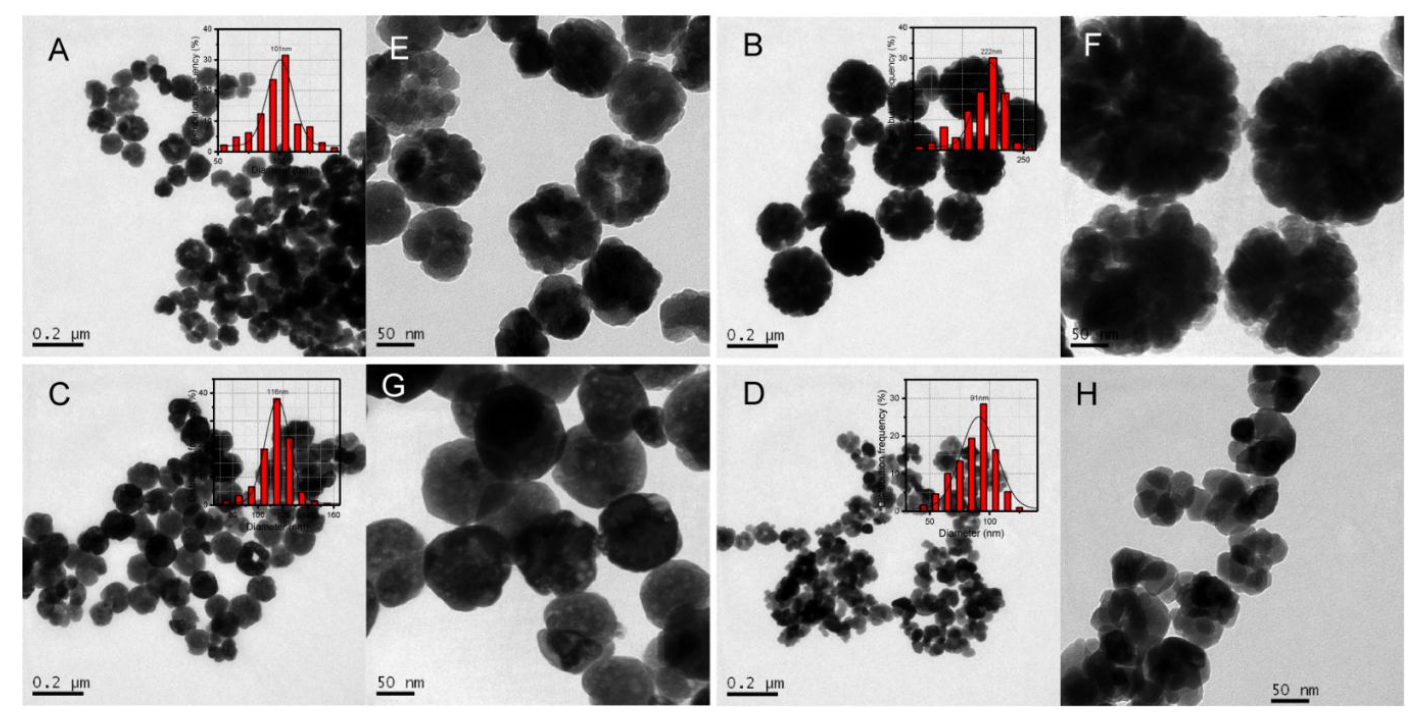

Figure 2. TEM images and size distribution patterns of $\mathrm{Fe}_{3} \mathrm{O}_{4}$ with different molar ratio of $\mathrm{FeCl}_{3} \cdot 6 \mathrm{H}_{2} \mathrm{O}$, (A) $0.4 \mathrm{mmol}$; (B) $5 \mathrm{mmol}$; (C) $10 \mathrm{mmol}$; (D) $20 \mathrm{mmol}$, the insets are the corresponding size distribution patterns. (E-H) is the corresponding magnification images.

Finally, the magnetic performances of as-obtained $\mathrm{Fe}_{3} \mathrm{O}_{4}$ NPs are investigated by VSM. The magnetization curves of the $\mathrm{Fe}_{3} \mathrm{O}_{4} \mathrm{NPs}$ are shown in Figure 4A,B. The magnetic saturation $\mathrm{Ms}$ values of the as-obtained $\mathrm{Fe}_{3} \mathrm{O}_{4} \mathrm{NPs}$ in Figure $4 \mathrm{~A}$ (a: S1, b: S2, c: S4) are 79.80, 62.50 and $53.43 \mathrm{emu} \cdot \mathrm{g}^{-1}$, respectively. The present coercivity $\left(H_{c}\right)$ values in Figure $4 \mathrm{~B}$ are about $100 \mathrm{Oe}(\mathrm{A} / \mathrm{m})$, indicating a very good soft magnetic property. Obviously, the $M s$ values of $\mathrm{Fe}_{3} \mathrm{O}_{4} \mathrm{NPs}$ increase gradually with the decreasing of $\mathrm{FeCl}_{3} \cdot 6 \mathrm{H}_{2} \mathrm{O}$. Figure $3 \mathrm{C}$ shows the photographs of the suspension of $\mathrm{Fe}_{3} \mathrm{O}_{4} \mathrm{NPs}$ with an external magnet application. The $\mathrm{Fe}_{3} \mathrm{O}_{4} \mathrm{NPs}$ can be easily dispersed in ethyl alcohol solution to form a black suspension, and it could also be drawn from the solution to the sidewall of the vial by an external magnetic field. The aggregate NPs could further re-dispersed in solution by removing the external field and slightly shaking.

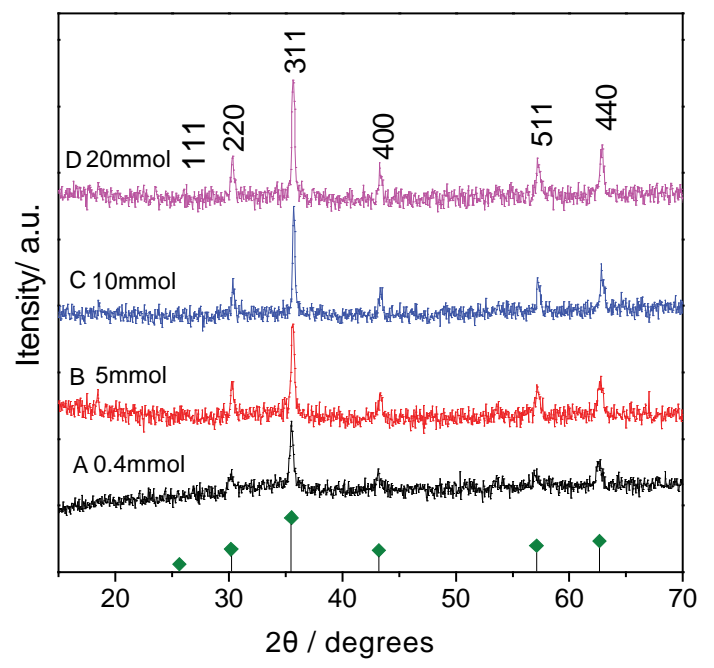

Figure 3. XRD patterns of $\mathrm{Fe}_{3} \mathrm{O}_{4}$ obtained with different molar ratio of $\mathrm{FeCl}_{3} \cdot 6 \mathrm{H}_{2} \mathrm{O}, \mathrm{A}: 0.4 \mathrm{mmol}$, B: $5 \mathrm{mmol}, \mathrm{C}: 10 \mathrm{mmol}, \mathrm{D}: 20 \mathrm{mmol}$. 

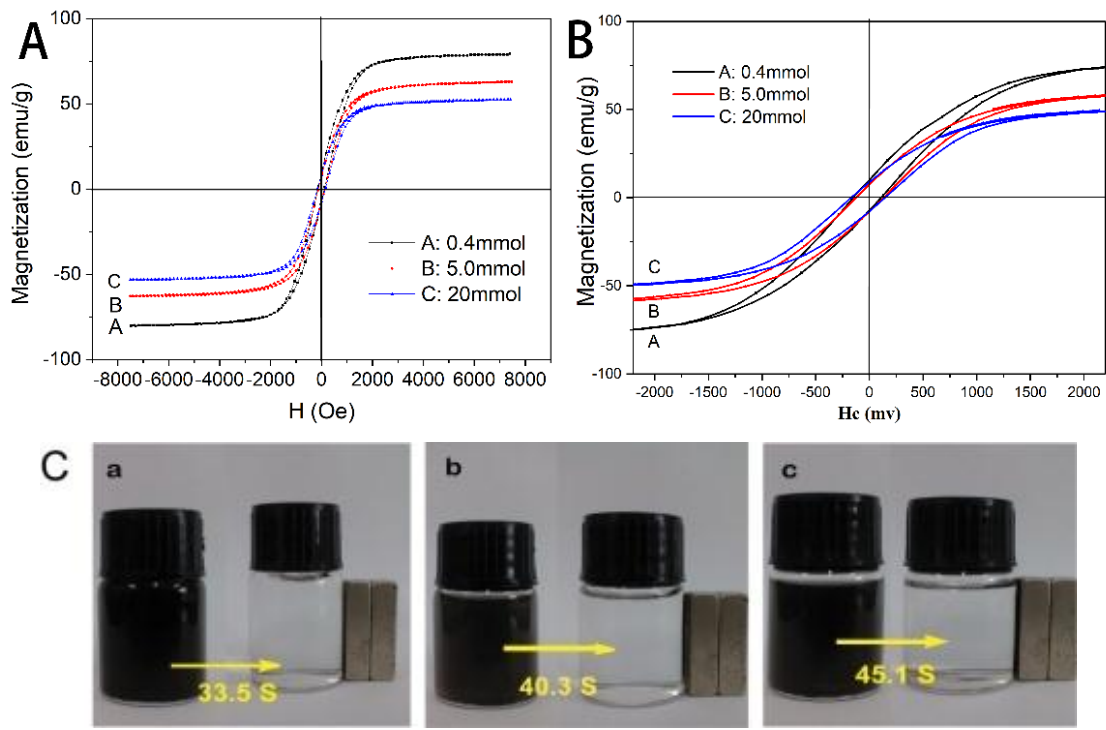

Figure 4. The hysteresis loops at $\mathrm{T}=300 \mathrm{~K}_{\text {of }} \mathrm{Fe}_{3} \mathrm{O}_{4}(\mathrm{~A})$ and corresponding partly amplification images (B) with different molar ratio of $\mathrm{FeCl}_{3} \cdot 6 \mathrm{H}_{2} \mathrm{O}$ (a) $0.4 \mathrm{mmol}$, (b) $5 \mathrm{mmol}$, (c) 20 mmol; (C) photograph of magnetic isolation.

\subsection{Morphology, Crystal Structure, and Magnetic Property of $\mathrm{Fe}_{3} \mathrm{O}_{4} \mathrm{NPs}$ with Different Amount of NaAc}

The amount of anhydrous NaAc could be the another factor to influence the morphologies and performances of $\mathrm{Fe}_{3} \mathrm{O}_{4}$ NPs. Five experimental groups with different anhydrous $\mathrm{NaAc}$ adding (5 mmol (S5), $10 \mathrm{mmol}$ (S6), $20 \mathrm{mmol}$ (S7), $40 \mathrm{mmol}$ (S8), $60 \mathrm{mmol}$ (S9)) are carried out for discussion the effect. Other synthetic conditions in each of these experiments are kept the same as those in the typical experiment, and the specific parameters are presented in Table 1. In the first place, the SEM images of S5-S9 are presented in Figure 5. As shown in these SEM images, the floccule is observed when $5 \mathrm{mmol} \mathrm{NaAc}$ is added. It indicates that these $\mathrm{Fe}_{3} \mathrm{O}_{4}$ are presented with smaller particle sizes. With increasing the NaAc to $10 \mathrm{mmol}$, the particle sizes of the $\mathrm{Fe}_{3} \mathrm{O}_{4}$ samples are increased obviously with better dispersity, which is observed in Figure 5B. Moreover, nearly monodispersed $\mathrm{Fe}_{3} \mathrm{O}_{4} \mathrm{NPs}$ with particle sizes between 100 and $200 \mathrm{~nm}$ are obtained when the NaAc is increased to $20 \mathrm{mmol}$ (Figure 5C). While the particle sizes of S8 and S9 become larger than S5-S7. These as-prepared $\mathrm{Fe}_{3} \mathrm{O}_{4}$ NPs show better dispersity and homogeneity.

Additionally, these samples are further characterized by TEM, and these TEM images and the corresponding particle size distribution of the as-prepared $\mathrm{Fe}_{3} \mathrm{O}_{4}$ particles are presented in Figure 6 . The homogeneity of S5 is very poor when $5 \mathrm{mmol}$ of anhydrous $\mathrm{NaAc}$ was added, and the mean particle size of these $\mathrm{Fe}_{3} \mathrm{O}_{4} \mathrm{NPs}$ (S5) is $85 \mathrm{~nm}$ with various morphologies (Figure 6A,F). After $10 \mathrm{mmol}$ of anhydrous NaAc adding, the $\mathrm{Fe}_{3} \mathrm{O}_{4}$ (S6) NPs in Figure 6B,G show the unconspicuous hollow structures with uniform size distribution. The average particle size is $122 \mathrm{~nm}$. When increasing the $\mathrm{NaAc}$ to $20 \mathrm{mmol}$, the flower-like $\mathrm{Fe}_{3} \mathrm{O}_{4} \mathrm{NPs}$ (S7) with average particle size of $103 \mathrm{~nm}$ are presented in Figure $6 \mathrm{C}, \mathrm{H}$. The mesoporous structure of these $\mathrm{Fe}_{3} \mathrm{O}_{4}$ NPs become more apparent. However, the evident hollow structures could be found with the increasing of anhydrous NaAc. The S8 show a better hollow structure in Figure 6D,I with mean particle size of $222 \mathrm{~nm}$, and their surface is smooth. S9 with mean particle size of $256 \mathrm{~nm}$ are presented in Figure 6E,J had a similar internal structure. 

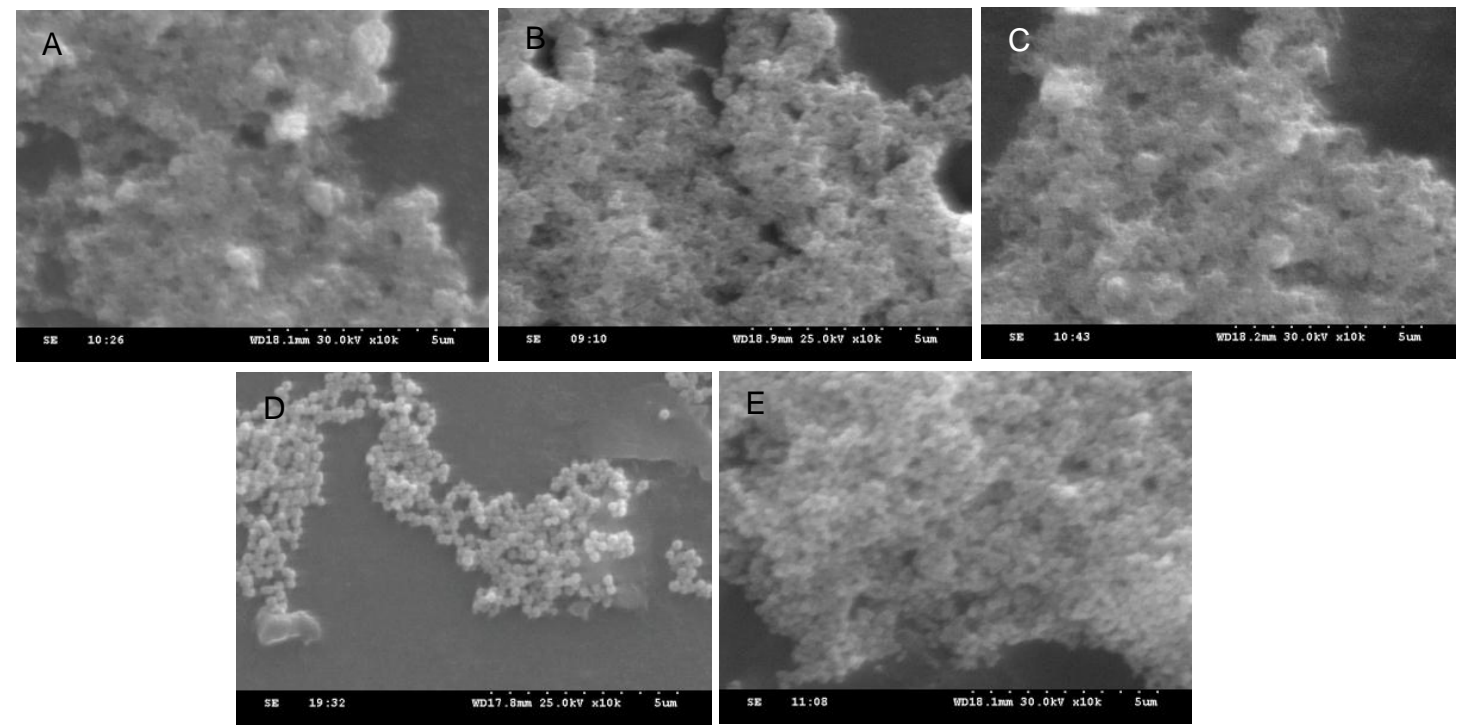

Figure 5. SEM images of $\mathrm{Fe}_{3} \mathrm{O}_{4}$ with different molar ratio of NaAc, (A) 5 mmol; (B) $10 \mathrm{mmol}$; (C) $20 \mathrm{mmol}$; (D) $40 \mathrm{mmol}$; (E) $60 \mathrm{mmol}$.
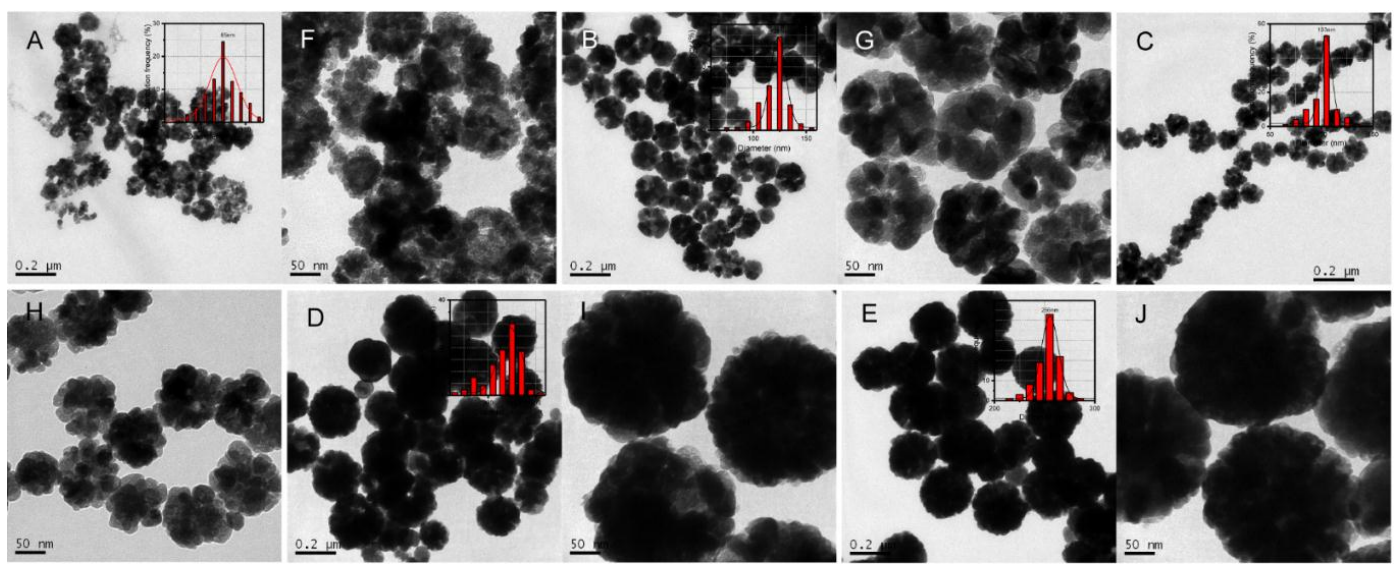

Figure 6. TEM images and size analysis patterns of $\mathrm{Fe}_{3} \mathrm{O}_{4}$ with different molar ratio of NaAc, (A) $5 \mathrm{mmol}$; (B) $10 \mathrm{mmol}$; (C) $20 \mathrm{mmol}$; (D) $40 \mathrm{mmol}$; (E) $60 \mathrm{mmol}$, the insets are the corresponding size distribution patterns; $(\mathbf{F}-\mathbf{J})$ is the corresponding magnification images, respectively.

Moreover, the XRD patterns of $\mathrm{Fe}_{3} \mathrm{O}_{4} \mathrm{NPs}$ (S5-S9) with different amount of NaAc are shown in Figure 7. The $\mathrm{XRD}$ is conducted to confirm the crystal structure and composition of the as-synthesized $\mathrm{Fe}_{3} \mathrm{O}_{4}$ NPs. As shown in Figure 7 , these peaks at $2 \theta=25.7^{\circ}, 30.4^{\circ}, 357^{\circ}, 43.2^{\circ}, 57.3^{\circ}$ and $62.8^{\circ}$ could be evidently observed in all curves, which are corresponding to the crystal planes of (111), (220), (311), (400), (511), (440) in $\mathrm{Fe}_{3} \mathrm{O}_{4}$ (JCPDS No. 01-1111, $\alpha=8.393 \AA$ ) Only these peaks of $\mathrm{Fe}_{3} \mathrm{O}_{4}$ NPs are observed, it indicates that the $\mathrm{Fe}_{3} \mathrm{O}_{4}$ NPs show good crystallinity with inverse spinel phase. However, the diffraction peaks of S5 are significantly lower than other samples, indicating the lower crystallization property of S5. These results demonstrate that NaAc show a distinctly influence on the crystallinity of $\mathrm{Fe}_{3} \mathrm{O}_{4}$ NPs. S6 show the best crystallization property and smaller particle size, which is facilitated to magnetic targeting drug delivery. 


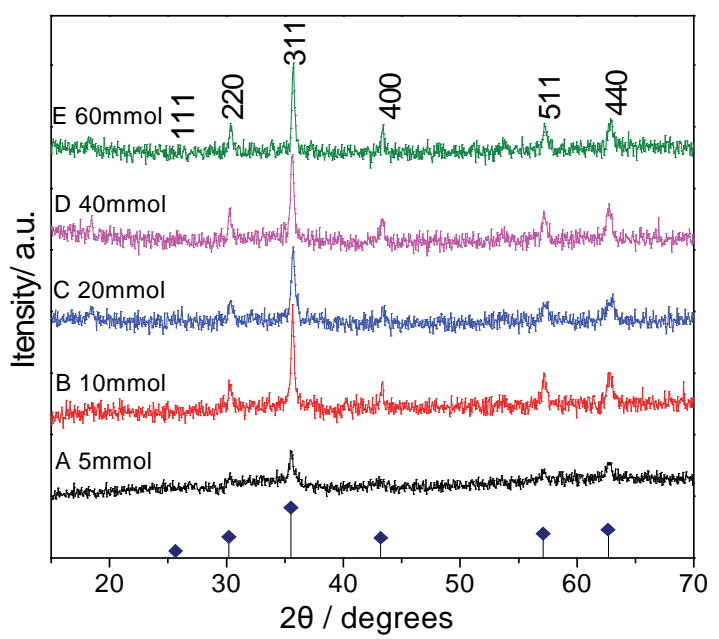

Figure 7. XRD patterns of $\mathrm{Fe}_{3} \mathrm{O}_{4}$ obtained with different molar ratio of $\mathrm{FeCl}_{3} \cdot 6 \mathrm{H}_{2} \mathrm{O}, \mathrm{A}: 0.4 \mathrm{mmol}$, B: $5 \mathrm{mmol}, \mathrm{C}: 10 \mathrm{mmol}$, D: $20 \mathrm{mmol}$.

The magnetization curves of the $\mathrm{Fe}_{3} \mathrm{O}_{4}$ NPs (S6, S8 and S9) are shown in Figure 8. The magnetic saturation $\mathrm{Ms}$ values of the obtained $\mathrm{Fe}_{3} \mathrm{O}_{4}$ NPs in Figure 8A (a: S6, b: S8, c: S9) are 49.64, 62.50 and $52.28 \mathrm{emu} \cdot \mathrm{g}^{-1}$, respectively. The present coercivity $H c$ values in Figure $8 \mathrm{~B}$ are less than $150 \mathrm{Oe}(\mathrm{A} / \mathrm{m})$, it indicates that these NPs show a good soft magnetic property. Figure $8 \mathrm{C}$ shows the photographs of the suspension of $\mathrm{Fe}_{3} \mathrm{O}_{4} \mathrm{NPs}$ (S6, S8 and S9) with an external magnet. The $\mathrm{Fe}_{3} \mathrm{O}_{4}$ NPs can be easily dispersed in ethyl alcohol solution to form a black suspension in $1 \mathrm{~min}$, and it could also be drawn from the solution to the sidewall of the vial by an external magnetic field. The aggregate NPs could further re-dispersed in solution by removing the external field and slightly shaking.
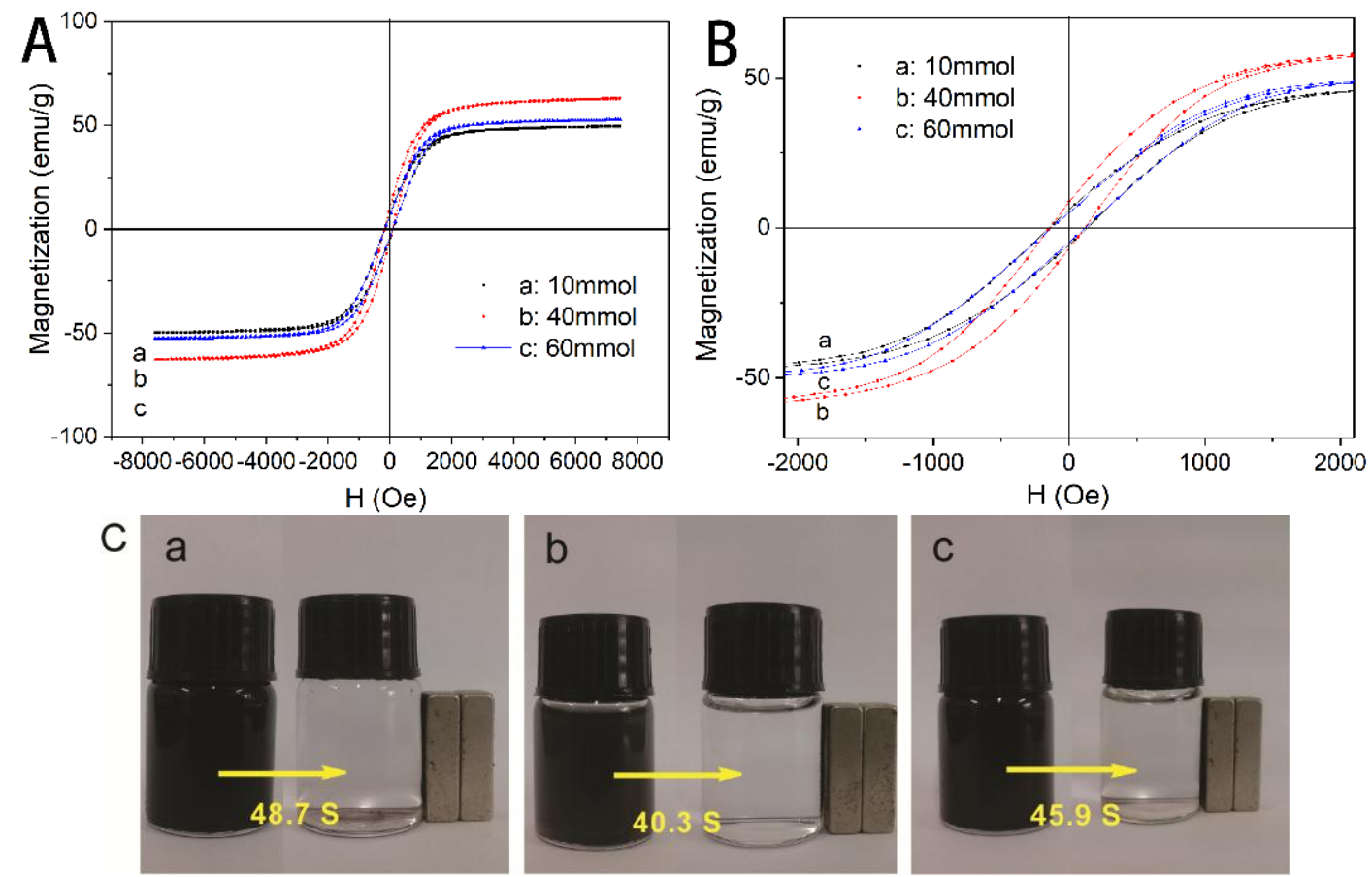

Figure 8. The hysteresis loops at $\mathrm{T}=300 \mathrm{~K}_{\text {of }} \mathrm{Fe}_{3} \mathrm{O}_{4}$ (A) and corresponding partly amplification images (B) with different molar ratio of NaAc (a) $10 \mathrm{mmol}$, (b) $40 \mathrm{mmol}$, (c) $60 \mathrm{mmol}$; (C) photograph showing magnetic isolation. 


\subsection{Morphology, Crystal Structure, and Magnetic Property of $\mathrm{Fe}_{3} \mathrm{O}_{4} \mathrm{NPs}$ with Different Reaction Time}

The reaction time during these hydrothermal routes is also considered. Six experimental groups under different reaction time $(5,6,8,10,12$ and $20 \mathrm{~h}$ ) are carried out, and these sample are named as S10-S15 respectively. Other synthetic conditions in each of these experimental groups are kept the same as those in the typical experiment, and the specific parameters are presented in Table 1. The mixture is transferred into a Teflon-lined stainless steel autoclave $(100 \mathrm{~mL}$ capacity) for hydrothermal treatment at $200{ }^{\circ} \mathrm{C}$. Firstly, the SEM images of S10-S15 are presented in Figure 9A-F, respectively. As shown in these images, with increasing the reaction time, the particle sizes of the $\mathrm{Fe}_{3} \mathrm{O}_{4}$ samples are increased obviously with good dispersity.
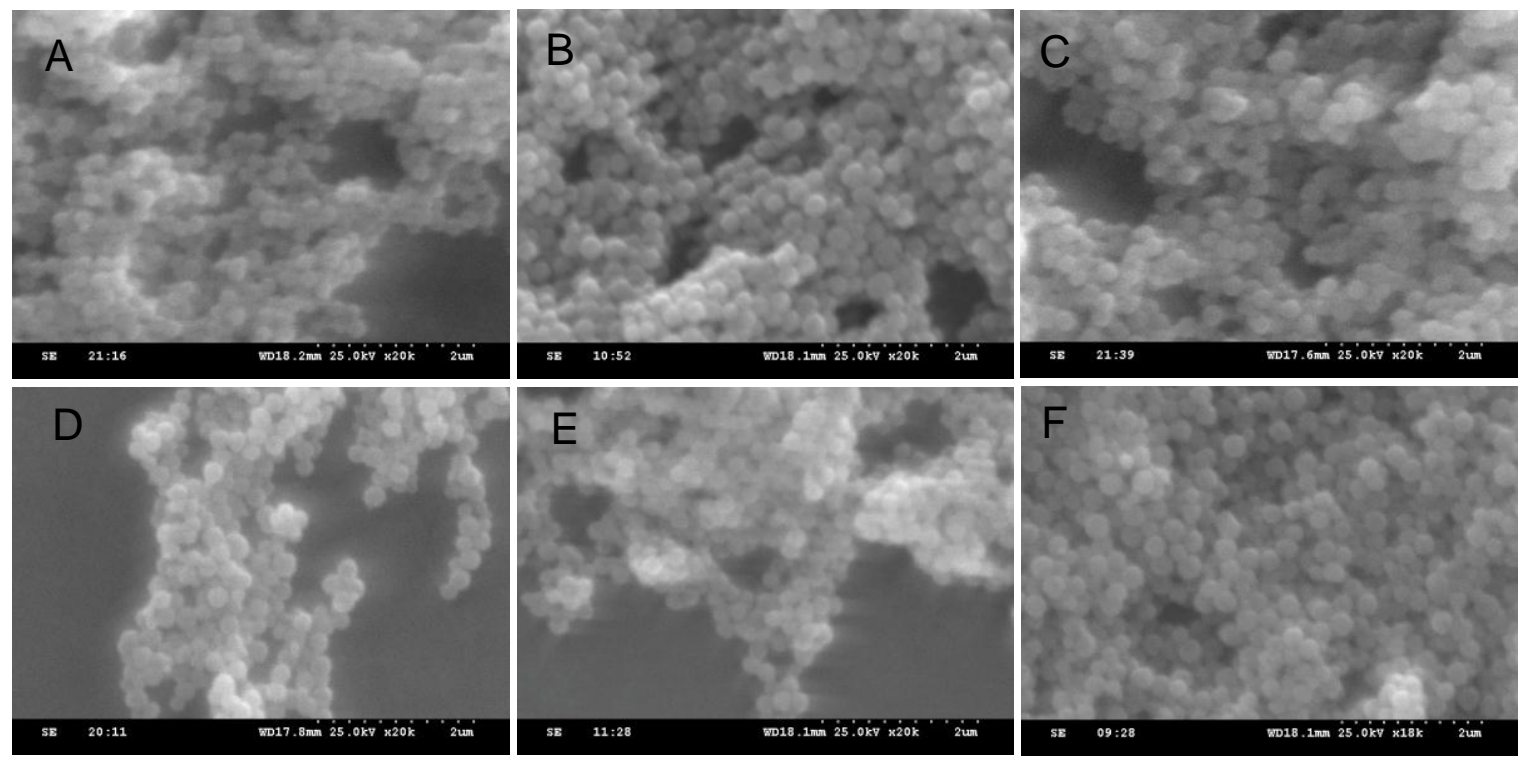

Figure 9. SEM images of $\mathrm{Fe}_{3} \mathrm{O}_{4}$ with different reaction time, (A) $5 \mathrm{~h},(\mathbf{B}) 6 \mathrm{~h},(\mathbf{C}) 8 \mathrm{~h}$, (D) $10 \mathrm{~h},(\mathrm{E}) 12 \mathrm{~h}$, (F) $20 \mathrm{~h}$.

In addition, the TEM images and the corresponding size distribution of the as-prepared $\mathrm{Fe}_{3} \mathrm{O}_{4}$ particles (S10-S15) are presented in Figure 10. With the prolonging of reaction time, the particle sizes of these $\mathrm{Fe}_{3} \mathrm{O}_{4}$ NPs (S10-S15) are increased gradually. As shown in the corresponding particle size distribution map, the average particle sizes of S10-S15 are $184 \mathrm{~nm}, 214 \mathrm{~nm}, 217 \mathrm{~nm}, 222 \mathrm{~nm}, 213 \mathrm{~nm}$ and $241 \mathrm{~nm}$, respectively. The narrow particle size distribution $\mathrm{Fe}_{3} \mathrm{O}_{4} \mathrm{NPs}$ could also be observed. Moreover, the hollow structure of all these $\mathrm{Fe}_{3} \mathrm{O}_{4}$ NPs could be observed clearly. However, with the prolonging of reaction time, as show in the magnified TEM images (Figure 10G-L), the hollow structure is increasingly apparent. These results indicate that the sizes and the hollow structures of as-obtained $\mathrm{Fe}_{3} \mathrm{O}_{4}$ NPs are increased with the extension of reaction time, because the time-dependent Ostwald ripening process could form the $\mathrm{Fe}_{3} \mathrm{O}_{4} \mathrm{NPs}$ with controllable hollow/mesoporous structures.

The XRD patterns of $\mathrm{Fe}_{3} \mathrm{O}_{4}$ NPs (S10-S15) with different reaction time are presented in Figure 11. The XRD is conducted to confirm the crystal structure $\mathrm{Fe}_{3} \mathrm{O}_{4} \mathrm{NPs}$. As shown in Figure 11, these curves show the characteristic peaks of $\mathrm{Fe}_{3} \mathrm{O}_{4} \mathrm{NPs}$, and only these peaks of $\mathrm{Fe}_{3} \mathrm{O}_{4} \mathrm{NPs}$ are observed, it indicates that the $\mathrm{Fe}_{3} \mathrm{O}_{4} \mathrm{NPs}$ show good crystallinity with inverse spinel phase. Moreover, the intensities of the peaks in all these curves are almost the same. It indicated that the crystal structure could not influence by the reaction time effectively. 


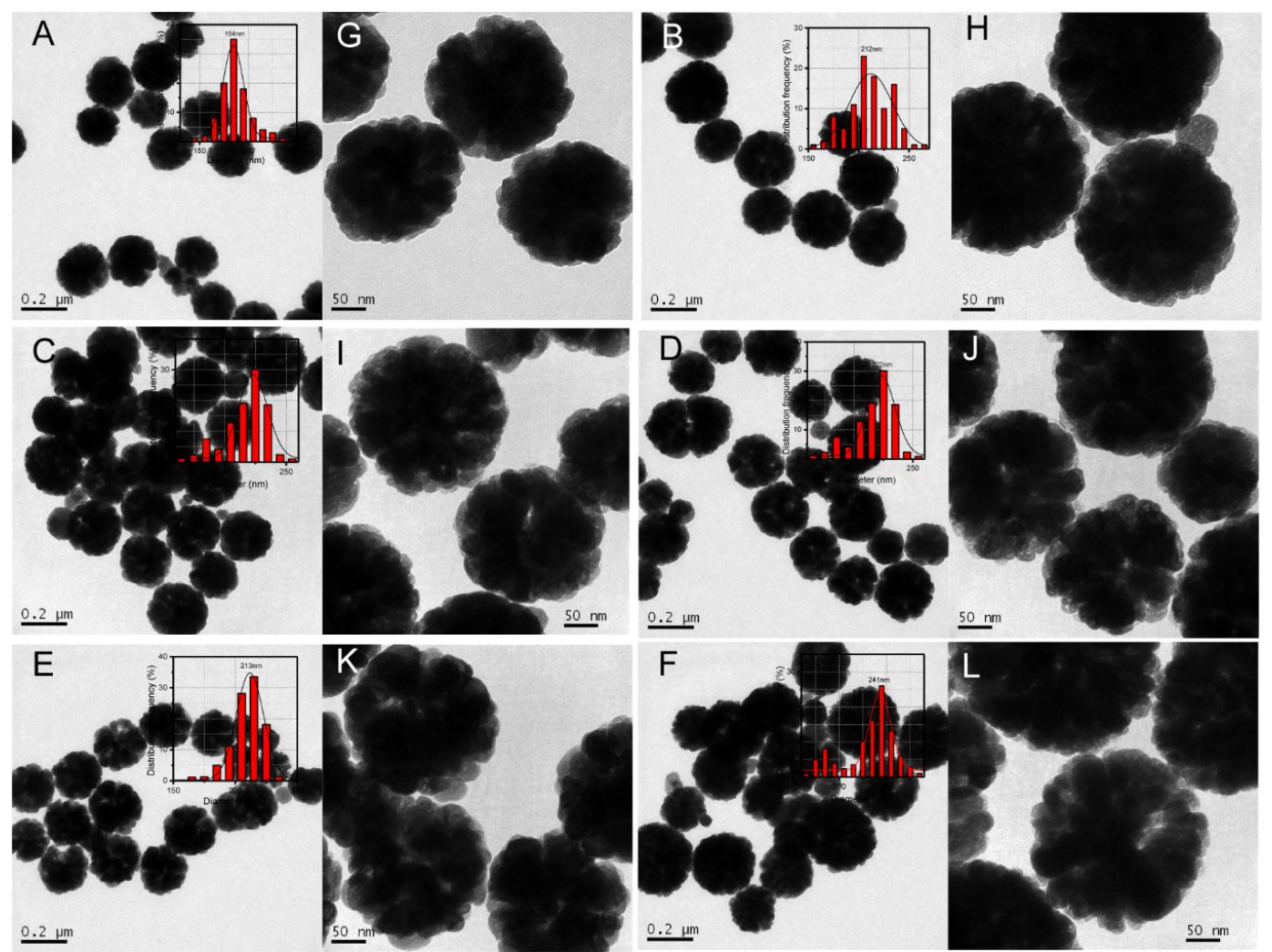

Figure 10. TEM images and size analysis patterns of $\mathrm{Fe}_{3} \mathrm{O}_{4}$ with different reaction time, (A) 5, (B) 6 , (C) 8, (D) 10, (E) 12, (F) 20 (h); the insets are the corresponding size distribution patterns. (G-L) is the corresponding magnification images respectively.

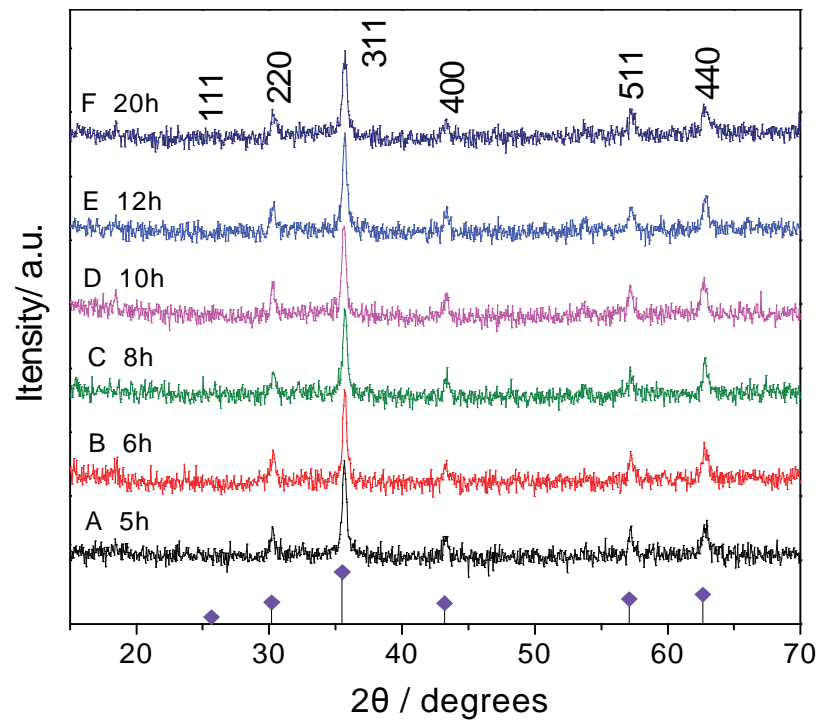

Figure 11. XRD patterns of $\mathrm{Fe}_{3} \mathrm{O}_{4}$ obtained with different reaction time, 5 h; B: 6 h; C: 8 h; D: 10 h; E: $12 \mathrm{~h} ; \mathrm{F}: 20 \mathrm{~h}$.

The magnetic property of these $\mathrm{Fe}_{3} \mathrm{O}_{4}$ NPs (S10-S15) are also investigated by VSM technique. The specific results are shown in Figure 12. The magnetic saturation $M s$ values of these as-obtained $\mathrm{Fe}_{3} \mathrm{O}_{4}$ NPs in Figure 12A (a: 5 h (S10), b: $10 \mathrm{~h}$ (S13), c: $20 \mathrm{~h}$ (S15)) are 71.42, 62.5 and $57.78 \mathrm{emu} \cdot \mathrm{g}^{-1}$, respectively. All of the $H c$ values in Figure $4 \mathrm{~B}$ are less than $100 \mathrm{Oe}(\mathrm{A} / \mathrm{m})$, this result indicate that these 
NPs are soft magnetic materials. Obviously, the obtained $\mathrm{Fe}_{3} \mathrm{O}_{4} \mathrm{NPs}$ exhibit the gradually decreased $M s$ values with the prolonging reaction time. Figure $12 \mathrm{C}$ shows the photographs of the suspension of S10, S13 and S15 with an external magnet. These $\mathrm{Fe}_{3} \mathrm{O}_{4}$ NPs could also be easy to aggregate and re-disperse in ethyl alcohol solution.
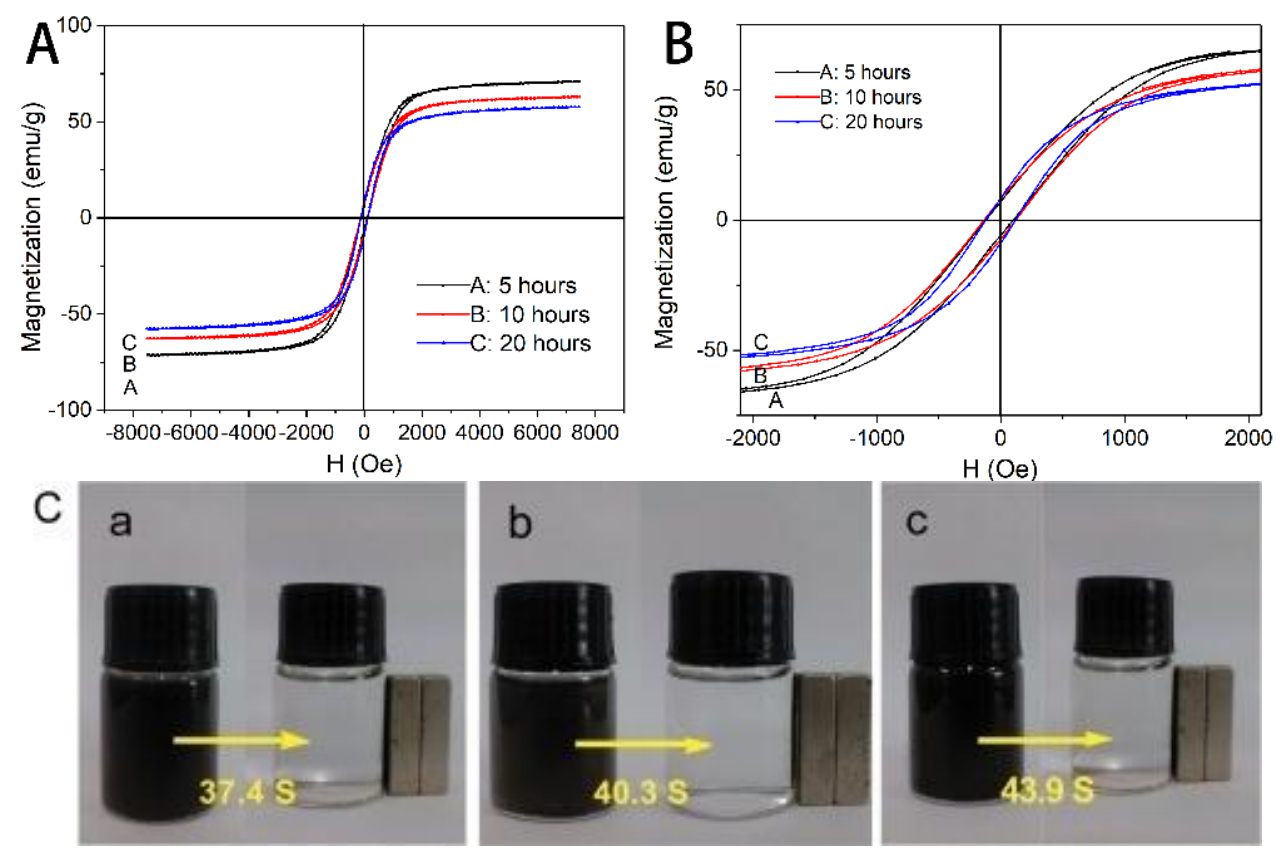

Figure 12. The hysteresis loops at $\mathrm{T}=300 \mathrm{~K}_{\text {of }} \mathrm{Fe}_{3} \mathrm{O}_{4}(\mathbf{A})$ and corresponding partly amplification images (B) with different reaction time (a) $5 \mathrm{~h}$, (b) $10 \mathrm{~h}$, (c) $20 \mathrm{~h}$; (C) photograph showing magnetic isolation.

\subsection{Formation Mechanism of $\mathrm{Fe}_{3} \mathrm{O}_{4} \mathrm{NPS}$}

These hollow/mesoporous $\mathrm{Fe}_{3} \mathrm{O}_{4}$ nanostructures are synthesized by solvothermal method. In the synthetic process, it is usually proposed that the EG acts both as a high-boiling-point solvent and a reducing agent, and sodium acetate provides as a structure-directive agent. Specifically, EG as a reducing agent is oxidized under heating to generate glycolaldehyde, as shown in formula (1). Then, glycolaldehyde can reduce $\mathrm{Fe}^{3+}$ to $\mathrm{Fe}^{2+}$, and the glyoxal is generated, as shown in formula (2). Moreover, with the increasing of temperature gradually, the $\mathrm{Fe}[\mathrm{Ac}]_{3}$ and $\mathrm{Fe}[\mathrm{Ac}]_{2}$ are formed by the reaction of $\mathrm{Ac}^{-}$and $\mathrm{Fe}^{3+}\left(\mathrm{Fe}^{2+}\right)$, such as the formulas (3) and (4). As the temperature rising, the $\mathrm{Fe}(\mathrm{OH})_{3}$ and $\mathrm{Fe}(\mathrm{OH})_{2}$ are formed by the hydrolytic and alcoholysis process of $\mathrm{Fe}[\mathrm{Ac}]_{3}$ and $\mathrm{Fe}[\mathrm{Ac}]_{2}$. These processes are shown in formulas (5)-(8). Finally, the followed $\mathrm{Fe}_{3} \mathrm{O}_{4}$ primary NPs are generated via dehydration of these hydrolytic products.

$$
\begin{gathered}
2 \mathrm{HOCH}_{2} \mathrm{CH}_{2} \mathrm{OH}+\mathrm{O}_{2} \stackrel{\Delta}{\rightarrow} 2 \mathrm{HOCH}_{2} \mathrm{CHO}+2 \mathrm{H}_{2} \mathrm{O} \\
\mathrm{HOCH}_{2} \mathrm{CHO}+2 \mathrm{Fe}^{3+} \rightarrow \mathrm{OHC}-\mathrm{CHO}+2 \mathrm{H}^{+}+2 \mathrm{Fe}^{2+} \\
\mathrm{Fe}^{3+}+3 \mathrm{Ac}^{-} \rightarrow \mathrm{Fe}[\mathrm{Ac}]_{3} \\
\mathrm{Fe}^{2+}+2 \mathrm{Ac}^{-} \rightarrow \mathrm{Fe}[\mathrm{Ac}]_{2} \\
\mathrm{Fe}[\mathrm{Ac}]_{3}+3 \mathrm{H}_{2} \mathrm{O} \stackrel{\Delta}{\rightarrow} \mathrm{Fe}(\mathrm{OH})_{3}+3 \mathrm{HAc} \\
\mathrm{Fe}[\mathrm{Ac}]_{2}+2 \mathrm{H}_{2} \mathrm{O} \stackrel{\Delta}{\rightarrow} \mathrm{Fe}(\mathrm{OH})_{2}+2 \mathrm{HAc} \\
\mathrm{Fe}[\mathrm{Ac}]_{3}+3 \mathrm{ROH} \stackrel{\Delta}{\rightarrow} \mathrm{Fe}(\mathrm{OH})_{3}+3 \mathrm{RAc}
\end{gathered}
$$




$$
\begin{gathered}
\mathrm{Fe}[\mathrm{Ac}]_{2}+2 \mathrm{ROH} \stackrel{\Delta}{\rightarrow} \mathrm{Fe}(\mathrm{OH})_{2}+2 \mathrm{RAc} \\
2 \mathrm{Fe}(\mathrm{OH})_{3}+\mathrm{Fe}(\mathrm{OH})_{2} \rightarrow \mathrm{Fe}_{3} \mathrm{O}_{4}+4 \mathrm{H}_{2} \mathrm{O}
\end{gathered}
$$

Afterwards, in order to reducing the surface energy, these $\mathrm{Fe}_{3} \mathrm{O}_{4}$ primary particles could aggregate with magnetic dipole alignment by oriented attachment mechanis [26]. The schematic diagram is presented in Figure 13. However, the formation of the hollow structures without using any templates in this formation process need be further understood. As the reaction goes on, the formation mechanism of these hollow $\mathrm{Fe}_{3} \mathrm{O}_{4} \mathrm{NPs}$ can further explained by Ostwald ripening mechanism. The inner primary particles could be dissolved and transformed into outer shell. In other words, reducing the overall surface energy provides the driving force for inner particles ripening. As a result, the large-scale synthesis of $\mathrm{Fe}_{3} \mathrm{O}_{4}$ nanospheres with hollow structures are formed finally.

Moreover, during the formation mechanism of these $\mathrm{Fe}_{3} \mathrm{O}_{4} \mathrm{NPs}$, the Ostwald ripening mechanism play an important role in formation of hollow structure. However, the influence of anhydrous $\mathrm{NaAc}$ to the performance of $\mathrm{Fe}_{3} \mathrm{O}_{4}$ NPs could also be taken into account. As shown in Table 1, the final $\mathrm{Fe}_{3} \mathrm{O}_{4} \mathrm{NPs}$ with mesoporous structure or amorphous structure are preferred to form, when the ratio of $\mathrm{FeCl}_{3} \cdot 6 \mathrm{H}_{2} \mathrm{O}$ and anhydrous $\mathrm{NaAc}$ is greater than 1:8. It means that the less anhydrous $\mathrm{NaAc}$ is facilitated to form the mesoporous structure. With the increasing of anhydrous $\mathrm{NaAc}$, the $\mathrm{Fe}_{3} \mathrm{O}_{4}$ NPs with hollow structure are easily formed. In these reactions, we infer that all these $\mathrm{Fe}^{3+}$ are participated into the reaction, about $1 / 3$ of $\mathrm{Fe}^{3+}$ could be reduced into $\mathrm{Fe}^{2+}$. Theoretically, the three times amount of $\mathrm{Ac}^{-}$could coordinate with $\mathrm{Fe}^{3+}$, and two times amount of $\mathrm{Ac}^{-}$could coordinate with $\mathrm{Fe}^{2+}$. Thus, the theoretical amount of $\mathrm{Ac}^{-}$could be obtained in Table 2. As shown in Table 2, the hollow structures are preferred to form, when the practical amount of $\mathrm{Ac}^{-}$is at least two times great than the theoretical amount. The NaAc is added and served not only as an electrostatic stabilization agent to prevent particle agglomeration, but also as an alkaline reagent for providing the alkaline reaction environment, which helps the $\mathrm{EG}$ to reduce the $\mathrm{Fe}^{3+}$ into $\mathrm{Fe}^{2+}$.

When the practical amount of $\mathrm{Ac}^{-}$is two times less than the theoretical amount, the insufficient $\mathrm{Ac}^{-}$is difficult to maintain the stability of this reaction system [27]. Therefore, the as-obtained $\mathrm{Fe}_{3} \mathrm{O}_{4}$ primary particles are easy to agglomerate rapidly with each other, under the Ostwald ripening mechanism, the $\mathrm{Fe}_{3} \mathrm{O}_{4}$ NPs with mesoporous structure are easily obtained (Figure 13, step C, and E). However, when the practical amount of $\mathrm{Ac}^{-}$is two times great than theoretical amount, the aggregated speed of these $\mathrm{Fe}_{3} \mathrm{O}_{4}$ primary particles is relatively lower, under the Ostwald ripening process, the $\mathrm{Fe}_{3} \mathrm{O}_{4}$ NPs with hollow structure could be formed gradually (Figure 13, Step D and F.). It is considered that the anhydrous $\mathrm{NaAc}$ is an associated structure-directing agent, it assists the formation of hollow and mesoporous structure with Ostwald ripening process. Thus, the $\mathrm{Fe}_{3} \mathrm{O}_{4} \mathrm{NPs}$ with controllable morphology, size and magnetic performance could be obtained by adjusting these synthetic condition $[28,29]$.

Table 2. The comparison of the theoretical amount and the practical amount of samples in specific experimental condition.

\begin{tabular}{ccccc}
\hline $\begin{array}{c}\mathbf{F e}^{3+} \text { Added } \\
\text { Amount (mmol) }\end{array}$ & $\begin{array}{c}\text { Ac } \\
\text { Amount (mmol) }\end{array}$ & $\begin{array}{c}\mathbf{F e}^{2+} \text { Theoretical } \\
\text { Amount (mmol) }\end{array}$ & $\begin{array}{c}\mathbf{F e}^{3+} \text { Theoretical } \\
\text { Amount (mmol) }\end{array}$ & $\begin{array}{c}\text { Ac }^{-} \text {Theoretical }_{\text {Amount (mmol) }} \\
\text { Amour }\end{array}$ \\
\hline 0.4 & 40 & 0.133 & 0.267 & 1.07 \\
5 & 40 & 1.667 & 3.333 & 13.33 \\
10 & 40 & 3.333 & 6.667 & 26.67 \\
20 & 40 & 6.667 & 13.333 & 53.33 \\
5 & 5 & 1.667 & 3.333 & 13.33 \\
5 & 10 & 1.667 & 3.333 & 13.33 \\
5 & 20 & 1.667 & 3.333 & 13.33 \\
5 & 40 & 1.667 & 3.333 & 13.33 \\
\hline
\end{tabular}




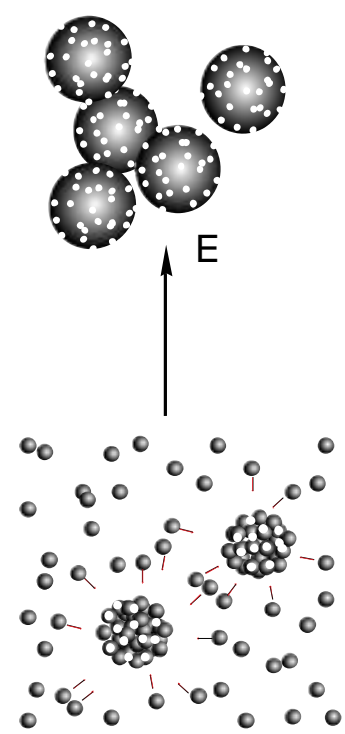

C

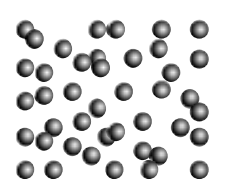

$\mid \begin{gathered}\text { A } \\ \text { Agglomeration }\end{gathered}$

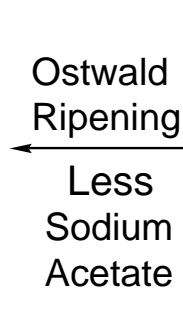

Sodium

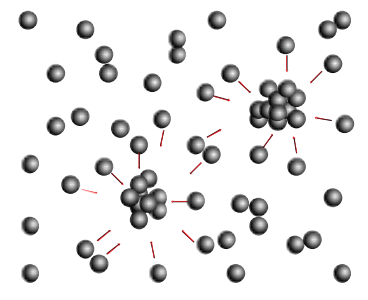

B

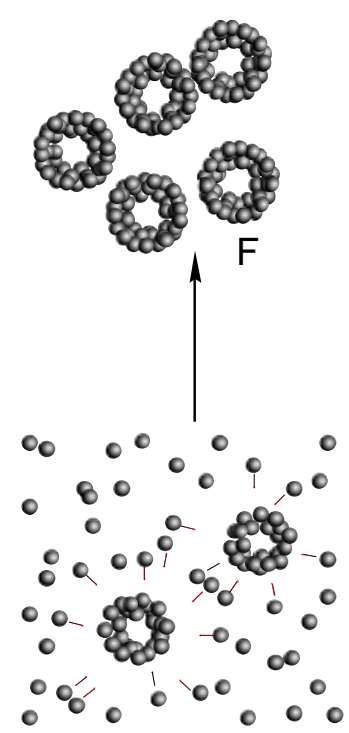

D

Figure 13. Schematic illustration of the process of magnetite mesoporous hollow spheres formation.

\section{Conclusions}

In summary, the one-pot solvothermal route is applied to prepare $\mathrm{Fe}_{3} \mathrm{O}_{4} \mathrm{NPs}$ with hollow and mesoporous structure. The different ratio of $\mathrm{FeCl}_{3} \cdot 6 \mathrm{H}_{2} \mathrm{O}$ and anhydrous $\mathrm{NaAc}$ show the great influence on the morphology, size, hollow structure and magnetic property of as-obtained $\mathrm{Fe}_{3} \mathrm{O}_{4} \mathrm{NPs}$. Moreover, with the prolonging the reaction time, the particle size become larger, and the hollow structure is getting evident gradually. The final $\mathrm{Fe}_{3} \mathrm{O}_{4} \mathrm{NPs}$ with obvious hollow structure, relatively smaller diameter $(<200 \mathrm{~nm})$ and satisfied magnetic performance are produced. The formation mechanism of these hollow or mesoporous structures is proposal as the NaAc assisted Ostwald ripening mechanism. This controllable method for synthesis of $\mathrm{Fe}_{3} \mathrm{O}_{4} \mathrm{NPs}$ could provide an excellent example for preparation of other magnetic nanomaterials. Moreover, the hollow $\mathrm{Fe}_{3} \mathrm{O}_{4} \mathrm{NPs}$ with well-defined structure and magnetic property show a good prospect in drug targeted delivery application.

Acknowledgments: This work was supported by Key Program of Hunan Provincial Department of Science and Technology (2016NK2096), China of Postdoctoral Science Foundation (2016M592456), Hunan Provincial Natural Science Foundation, Doctoral construction program of Hunan University of Technology, Project of Science and Technology Department of Hunan Province, and Zhuzhou Science and Technology Plans (201707-201806).

Author Contributions: Quanguo He, Jun Liu and Wen Li conceived and designed the experiments; Jun Liu and Jing Liang performed the experiments; Jun Liu, Quanguo He and Xiaopeng Liu analyzed the data; Quanguo He, Ziyu Ding and Du Tuo contributed reagents/materials/analysis tools; Quanguo He and Jun Liu wrote the paper.

Conflicts of Interest: The authors declare no conflict of interest.

\section{References}

1. Xiong, Q.Q.; Tu, J.P.; Lu, Y.; Chen, J.; Yu, Y.X.; Qiao, Y.Q.; Wang, X.L.; Gu, C.D. Synthesis of Hierarchical Hollow-Structured Single-Crystalline Magnetite $\left(\mathrm{Fe}_{3} \mathrm{O}_{4}\right)$ Microspheres: The Highly Powerful Storage versus Lithium as an Anode for Lithium Ion Batteries. J. Phys. Chem. C 2012, 116, 6495-6502. [CrossRef]

2. Dorniani, D.; Hussein, M.Z.B.; Kura, A.U.; Fakurazi, S.; Shaari, A.H.; Ahmad, Z. Preparation of $\mathrm{Fe}_{3} \mathrm{O}_{4}$ magnetic nanoparticles coated with gallic acid for drug delivery. Int. J. Nanomed. 2012, 7, 5745-5756. [CrossRef] [PubMed]

3. Liu, J.; Huang, C.; He, Q. Pharmaceutical Application of Magnetic Iron Oxide Nanoparticles. Sci. Adv. Mater. 2015, 7, 672-685. [CrossRef]

4. He, Q.; Liu, J.; Huang, C.; Wu, W. Synthesis and Characterization of a Silver Incorporated Magnetic Nanocomposite with Enhanced Antibacterial Activity. Sci. Adv. Mater. 2014, 6, 366-376. [CrossRef] 
5. He, Q.; Liu, J.; Huang, C.; Wu, Z. A Nanoscale System for Remarkably Enhanced Drug Delivery Based on Hollow Magnetic Particles Encapsulated Within Temperature-Responsive Poly(methylmethacrylate). Sci. Adv. Mater. 2014, 6, 387-398. [CrossRef]

6. Yu, J.; Yu, X.; Huang, B.; Zhang, X.; Dai, Y. Hydrothermal Synthesis and Visible-light Photocatalytic Activity of Novel Cage-like Ferric Oxide Hollow Spheres. Cryst. Growth Des. 2009, 9, 1474-1480. [CrossRef]

7. An, K.; Kwon, S.G.; Park, M.; Na, H.B.; Baik, S.-I.; Yu, J.H.; Kim, D.; Son, J.S.; Kim, Y.W.; Song, I.C.; Moon, W.K.; Park, H.M.; Hyeon, T. Synthesis of Uniform Hollow Oxide Nanoparticles through Nanoscale Acid Etching. Nano Lett. 2008, 8, 4252-4258. [CrossRef] [PubMed]

8. Cheng, K.; Peng, S.; Xu, C.; Sun, S. Porous Hollow $\mathrm{Fe}_{3} \mathrm{O}_{4}$ Nanoparticles for Targeted Delivery and Controlled Release of Cisplatin. J. Am. Chem. Soc. 2009, 131, 10637-10644. [CrossRef] [PubMed]

9. Wei, J.; Du, A.; Jin, F.; Wang, Z.; Liu, X. The preparation and high-frequency electromagnetic properties of ferrimagnetic bisphthalonitrile--Fe ${ }_{3} \mathrm{O}_{4}$ core-shell hollow microspheres. J. Magn. Magn. Mater. 2013, 340, 70-75. [CrossRef]

10. Yang, S.; Liu, H.; Zhang, Z. Fabrication of Novel Multihollow Superparamagnetic Magnetite/Polystyrene Nanocomposite Microspheres via Water-in-Oil-in-Water Double Emulsions. Langmuir 2008, 24, 10395-10401. [CrossRef] [PubMed]

11. Ostwald, W. Studien über die Bildung und Umwandlung fester Körper. Zeitschrift für Physikalische Chemie 1897, 22U, 289-330.

12. Peng, S.; Sun, S. Synthesis and Characterization of Monodisperse Hollow $\mathrm{Fe}_{3} \mathrm{O}_{4}$ Nanoparticles. Angew. Chem. Int. Edit. 2007, 46, 4155-4158. [CrossRef] [PubMed]

13. Wang, Q.; Geng, B.; Wang, S.; Ye, Y.; Tao, B. Modified Kirkendall effect for fabrication of magnetic nanotubes. Chem. Commun. 2010, 46, 1899-1901. [CrossRef] [PubMed]

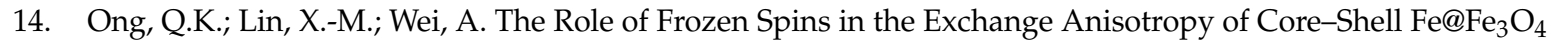
Nanoparticles. J. Phys. Chem. C 2011, 115, 2665-2672. [CrossRef] [PubMed]

15. Chae, H.S.; Piao, S.H.; Choi, H.J. Fabrication of spherical $\mathrm{Fe}_{3} \mathrm{O}_{4}$ particles with a solvothermal method and their magnetorheological characteristics. J. Ind. Eng. Chem. 2015, 29, 129-133. [CrossRef]

16. Ren, Y.; Zhang, H.; Chen, B.; Cheng, J.; Cai, X.; Liu, R.; Xia, G.; Wu, W.; Wang, S.; Ding, J.; Gao, C.; Wang, J.; Bao, W.; Wang, L.; Tian, L.; Song, H.; Wang, X. Multifunctional magnetic $\mathrm{Fe}_{3} \mathrm{O}_{4}$ nanoparticles combined with chemotherapy and hyperthermia to overcome multidrug resistance. Int. J. Nanomed. 2012, 7, 2261-2269.

17. Zhang, W.; Qiao, L.; Wang, X.; Senthilkumar, R.; Wang, F.; Chen, B. Inducing cell cycle arrest and apoptosis by dimercaptosuccinic acid modified $\mathrm{Fe}_{3} \mathrm{O}_{4}$ magnetic nanoparticles combined with nontoxic concentration of bortezomib and gambogic acid in RPMI-8226 cells. Int. J. Nanomed. 2015, 10, 3275-3289.

18. He, Q.; Liu, J.; Hu, R. Facile Magnetosensitive Catalyst Fabrication of Palladium/Platinum Coated Maghemite Nanocomposites and Characterization. Nanosci. Nanotechnol. Lett. 2013, 5, 995-1001. [CrossRef]

19. Wu, W.; He, Q.; Chen, H.; Tang, J.; Nie, L. Sonochemical synthesis, structure and magnetic properties of air-stable $\mathrm{Fe}_{3} \mathrm{O}_{4} / \mathrm{Au}$ nanoparticles. Nanotechnology 2007, 18, 145609. [CrossRef]

20. Akbarzadeh, A.; Mikaeili, H.; Zarghami, N.; Mohammad, R.; Barkhordari, A.; Davaran, S. Preparation and in vitro evaluation of doxorubicin-loaded $\mathrm{Fe}_{3} \mathrm{O}_{4}$ magnetic nanoparticles modified with biocompatible copolymers. Int. J. Nanomed. 2012, 7, 511.

21. Liu, J.; Yang, S.; Wu, W.; Tian, Q.; Cui, S.; Dai, Z.; Ren, F.; Xiao, X.; Jiang, C. 3D flowerlike $\alpha-\mathrm{Fe}_{2} \mathrm{O}_{3} @ \mathrm{TiO}_{2}$ core-shell nanostructures: general synthesis and enhanced photocatalytic performance. ACS Sustainable Chem. Eng. 2015, 3, 2975-2984. [CrossRef]

22. An, J.S.; Han, W.J.; Choi, H.J. Synthesis of hollow magnetite nanoparticles via self-assembly and their magnetorheological properties. Colloid. Surfaces A 2017, 535, 16-23. [CrossRef]

23. Lin, X.; Ji, G.; Liu, Y.; Huang, Q.; Yang, Z.; Du, Y. Formation mechanism and magnetic properties of hollow $\mathrm{Fe}_{3} \mathrm{O}_{4}$ nanospheres synthesized without any surfactant. CrystEngComm 2012, 14, 8658-8663. [CrossRef]

24. He, Q.; Wu, Z.; Huang, C. Dual gas-bubble-assisted solvothermal synthesis of magnetite with tunable size and structure. J. Nanosci. Nanotechnol. 2011, 11, 8568-8575. [CrossRef] [PubMed]

25. He, Q.; Liu, J.; Liu, X.; Li, G.; Deng, P.; Liang, J. Preparation of $\mathrm{Cu}_{2} \mathrm{O}$-Reduced Graphene Nanocomposite Modified Electrodes towards Ultrasensitive Dopamine Detection. Sensors 2018, 18, 199. [CrossRef] [PubMed]

26. Tian, X.; Li, J.; Chen, K.; Han, J.; Pan, S.; Wang, Y.; Fan, X.; Li, F.; Zhou, Z. Nearly monodisperse ferroelectric $\mathrm{BaTiO}_{3}$ hollow nanoparticles: size-related solid evacuation in ostwald-ripening-induced hollowing process. Cryst. Growth Des. 2010, 10, 3990-3995. [CrossRef] 
27. Deng, H.; Li, X.; Peng, Q.; Wang, X.; Chen, J.; Li, Y. Monodisperse magnetic single crystal ferrite microspheres. Angew. Chem. 2005, 117, 2842-2845. [CrossRef]

28. Liu, S.; Xing, R.; Lu, F.; Rana, R.K.; Zhu, J.-J. One-pot template-free fabrication of hollow magnetite nanospheres and their application as potential drug carriers. J. Phys. Chem. C 2009, 113, 21042-21047. [CrossRef]

29. He, Q.; Liu, J.; Liang, J.; Liu, X.; Tuo, D.; Li, W. Chemically Surface Tunable Solubility Parameter for Controllable Drug Delivery-An Example and Perspective from Hollow PAA-Coated Magnetite Nanoparticles with R6G Model Drug. Materials 2018, 11, 247. [CrossRef] [PubMed] 